\title{
Review
}

\section{Diversity and Distribution of Curry Leaf in India}

\author{
Raghu B.R. \\ Division of Vegetable Crops \\ ICAR-Indian Institute of Horticultural Research, Bangalore - 560089. \\ Email : ragubr@gmail.com
}

\begin{abstract}
Curry leaf is an aromatic tropical and sub-tropical plant originated from India. Besides its culinary purpose, curry leaf is known for its medicinal and industrial applications. Based on ethno-botanical reports and other floral distribution studies, the germplasm rich regions of curry leaf in India could be identified into six zones as Foot hills of Himalaya, North-East region, Middle India, Eastern Ghats, Western Ghats and Andaman - Nicobar Islands. With respect to color and size of leaves, habitat and flavor, the curry leaf plant is classified as brown/ gamthi, regular and dwarf morphotypes. Four genetically diverse chemotypes of curry leaves such as $\beta$-pinene, $\alpha$-pinene, $\beta$-carophyllene and $\beta$-phellandrene exist in India. Due to its nutritional value, increasing export potential, less input, lower cost of cultivation, assured income, perennial nature and constant demand in local, national and international markets, the curry leaf is being cultivated on commercial scale in recent years in India.
\end{abstract}

Key words: Curry leaves, Distribution, Diversity, Germplasm and Morphotypes

\section{INTRODUCTION}

Curry leaf (Murraya koenigii (L.) Spreng) is an aromatic, tropical and sub-tropical plant with several culinary, nutraceutical, medicinal, therapeutic and industrial values (Reddy et al., 2018). It is an important and indispensible part of Indian cuisine (Verghese, 1989). The ethno-botanical use of curry leaf for medicinal purposes is known since centuries. Carbazole alkaloids present abundantly in curry leaves have anticancer, anti-diabetic and anti-oxidant properties (Igara et al., 2016). The essential oils extracted from curry leaf plant have several industrial applications in the manufacturing of soaps, perfumes, cosmetics, food processing and many others. As curry leaf is a rich source of bio-available calcium and other essential nutrients, it makes an important component of Indian diet and imparts several direct and indirect health benefits to its consumers. As curry leaf is a perennial leafy vegetable, it provides assured income to small and marginal farmers if cultivated on commercial scale and earns considerable amount of foreign returns through export particularly to Gulf and European Unions (Joseph and Peter, 1985).
Regardless of its numerous benefits and several applications, curry leaf is still an unexplored and underutilized crop. This is evident from inadequate efforts being put towards the collection, characterization, conservation and efficient utilization of plant genetic resources (PGR) for crop improvement and limited area of cultivation under this crop. However, understanding the extant of variability, distribution pattern and identification of germplasm rich regions are the prerequisites in any crop improvement program. Furthermore, accelerated use and augmentation of available PGR, identification of trait specific genotypes, mapping and introgression of economically important gene(s)/QTLs (Quantitative Trait Loci) into well adapted and elite genetic background are sign of more efficient and rapid genetic improvement program in any crop species and so with the curry leaf. Moreover, efficient breeding programmes should backup with detailed survey and frequent collaborative germplasm exploration trips to cover wide range of variability, followed by regular exchange and characterization of germplasm between 
the breeders. In addition, development of various robust genomic resources and their efficient use in rapid germplasm screening and detection of elite genotypes and traits discovery. Thus, in the present article efforts are made to throw a light on diversity and distribution pattern of curry leaves and its present status of genetic improvement in India.

\section{BOTANY}

Curry leaf belongs to the family Rutaceae and the genus Murraya J. Koenig ex L (Satyavati et al., 1987). It is true diploid with chromosome number, $2 \mathrm{n}=18(\mathrm{x}=9)$ (Raghvan, 1957). It is found in various tropical and subtropical regions of the world (Smith, 1985). It is a semi-deciduous, aromatic, pubescent and unarmed shrub or small tree capable of growing up to 6 meter height with slender but strong woody stem (Figure 1). Later, the woody stem develops into densely crowded shaded crown. The leaves of curry leaf plant are alternate, estipulate, bipinnately compound, glabrous, $15-20 \mathrm{~cm}$ long, rarely pubescent at young and gland dotted and extremely strongly aromatic with numerous volatile compounds. The leaflets are alternate and short stalked; ovate to ovate lanceolate in shape with number varies from 9 to 12 or more per leaf. The leaves are slightly pungent, bitter and aciduous in taste. The major chemical compounds responsible for characteristic intense aroma and flavor are sabinene, pinene, cadinol, caryophyllene and cadinene (Singh et al., 2014). Monoterpenoids and their oxygenated derivatives are the chief chemical constituents present in essential oil of curry leaf (Singh et al., 2014). The essential oils extracted from fresh leaves collected from different parts of Western Ghats, India contains significant amount of monoterpene hydrocarbons such as sabinene (6.90-40.59\%), $\beta$-phellandrene (1.39$45.89 \%)$ and $\alpha$-pinene (1.93-63.66\%), and a sesquiterpene hydrocarbon $\beta$-caryophyllene (6.68$18.46 \%$ ) (Syamasunder et al., 2012).

Curry leaf is highly self-pollinated crop. The flowers are bisexual, produced many in a terminal pedunculate inflorescence arranged compact, corymbiform and cymose panicle. The bisexual flowers are very small measuring about a $\mathrm{cm}$ length, white and fragrant. The flowers contain five deeply cleft and pubescent calyx, five free and spreading petals, ten freely and alternatively arranged short and long, linear and subulate stamens with small and short anthers. The style is thick, elongated, cylindrical and articulate with capitate or grooved stigma. The flowering occurs mainly in the middle of April to middle of May reaching its peak in last week of April. The curry leaf plant bears small berries, measuring 1-2 $\mathrm{cm}$ diameter with thin pericarp and mucilaginous pulp enclosing 1 or 2 seeds. The fruiting starts from middle of July and continue up to end of August. Upon ripening, the fruits turn red and ultimately black and seeds are non endospermic with membranous and glabrous testa bearing small embryo. Propagation occurs either through seeds or rooted suckers.

\section{ORIGIN AND DISTRIBUTION}

The curry leaf originated from Indian sub-continent including Andaman and Nicobar Islands, Sri Lanka and Bangladesh (Joseph and Peter, 1985), later expanded to different parts of the world by Indian migrants. Presently, it is grown in various tropical and subtropical regions such as, India, Sri Lanka, Bhutan, Nepal, Malaysia, Southern China, Guangdong, Southern Hainan, Southern Yunnan, Laos, Vietnam, Thailand, Mariana Islands, Vanuatu, New Caledonia, Ryuku Islands, Australia and South Africa (Smith, 1985).

Curry leaf is widely distributed throughout India except in higher altitudes of Himalayas. It is found abundantly in forests and waste lands in natural, wild and cultivated forms up to $1650 \mathrm{~m}$ altitude (Joseph and Peter, 1985). In southern India, it is found in homestead gardens of every household (Joseph and Peter, 1985). Based on several ethno-botanical reports and other floral distribution studies, the germplasm rich regions of curry leaf could be identified into six zones for future exploration and genetic improvement in India (Figure 2).

Region-1: This region is confined to sub-tropical forests running all along the sub-Himalayan foothills from Jammu \& Kashmir, Himachal Pradesh, Uttarakhand to Terai regions of Uttar Pradesh and Bihar (Figure 2). In Himachal Pradesh, curry leaf is found in the forest ranges found between Tanda and Shahpur in Kangra district, Nalagarh and Nahan-Paonta ranges in Sirmaur district and some warmer areas of Solan, Shimla, Bilaspr, Hamirpur and Mandi districts. In Uttarakhand, sub-tropical forests in foot hills of Shivalik of Dehradun and Gharwal and Udham Singh Nagar including Rajaji national park and sub-tropical forests of Kumoan 
regions of Almora, Nainital and Champavat districts are rich in curry leaf. The Terai regions of Uttar Pradesh covering 15 districts (Saharanpur, Muzaffarnagar, Bijnor, Moradabad, Rampur, Bareilly, Pilibhit, Kheri, Bahraich, Shravasti, Balrampur, Siddharth, Mahrajganj, Kushinagar, Gorakhpur) including Dudhwa national park, and West-Champaran, East-Champaran and Gopalganj districts of Bihar are rich sources of curry leaf.

Region-2: The region is confined to tropical evergreen and semi-evergreen, and tropical moist and dry deciduous forests of North-eastern states (Figure 2). This region covers from foot hills of South Sikkim, Darjeeling, Jalpaiguri and Cooch Behar districts of west Bengal. The Assam valley includes Brahmaputra valley, Barak valley, Karbi plateau and Barail hills and parts of South Kamrup, Sibsagar, North Lakhimpur, Cachar, Goalpara, Nowgoan and Darrang districts of Assam. East and West Kameng, lower \& Upper Subansiri, Lohit and Tirap districts in Arunachal Pradesh. Southern and Northern slopes of Meghalaya including Northern and North-western slopes of Garo hills. Western and North-western parts of Nagaland. Jiri, Moreh, Vangoi, Tamenglong forest areas and forest areas adjacent to Myanmar in Manipur. Dharam Nagar, Kailashahr, Belonia, Amarpur, Sonamura, Udiapur and Sadar sub-division in Tripura. Northern side forest areas of Kawnpuri, Hortaki, Bhairabi, Kolarib, Vairentee and western parts of Mizoram. Besides, the curry leaf is an integral part of many tribal medicines and hence it could be seen commonly in home-stead gardens in north eastern states.

Region-3: This region is confined to central India, from Sundarban delta to Satpur range covering Chotanagpur plateau, Hazaribagh plateau, Ramgarh hills, Malayagiri, Dandakaranya and Vindhyan ranges (Figure 2). Unlike regions $1 \& 2$, this region is loosely spread over South-western parts of West Bengal, Jharkhand, Northern parts of Odisha, Chhattisgarh, and Northern parts of Maharashtra to Madhya Pradesh including Southern Uttar Pradesh. A pursuance of review of literature of ethno-botanical use and floral and medicinal plants diversity studies of curry leaf in central India indicated that, it has been grown and used in Sonebhadra district of Uttar Pradesh, Jabalpur, Neemuch, Raisen, Rewa, Umaria, Anuppur, Nimar eco-region, Satpur plateau of Madhya Pradesh, Bhadrak, Koraput, Jharsuguda, Keonjhar districts, Rourkela, Nandan Kanan wild life sanctuary of Odisha, Mahasamund, Dantewada, Koria, Jashpur, Raipur, Surguja, Ratanpur region of Bilaspur, Raigarh area, Bhoramdeo wild life sanctuary, Kabirdham wild life sanctuary of Chhattisgarh, Dumka of Jharkhand, Bhagalpur, Banka, Buxar of Bihar and Burdwan, Hoogly, South 24 Parganas, Birbhum, West Rarrh region of West Bengal.

Region-4: This region is confined to Eastern parts of India mainly covering Eastern Ghats (Figure 2). This region starts from Southern parts of Odisha, covering Andhra Pradesh and up to Northern Tamil Nadu.

Region-5: This region is confined to Western parts of India mainly covering Western Ghats (Figure 2). This region starts from Southern parts of Gujarat, covering, Maharashtra, Goa, Karnataka and up to Kerala.

Region-6: This region is confined to Andaman and Nicobar islands mainly covering the Andaman semi-evergreen forests, Andaman moist deciduous forests and Andaman secondary moist deciduous forests (Figure 2).

\section{NUTRITIONAL POTENTIAL OF CURRY LEAVES}

The fresh and dried leaves of curry plant are used for flavoring the food stuffs. It is good sources of minerals (Calcium, Phosphorus, Iron, Zinc, Magnesium), vitamins (A, E, B, C), and are rich in carbohydrates, proteins, amino acids and fibre. Besides, leaves contains alkaloids, flavonoids, phenols, saponins, steroids, quinones, tannins and other bio-active compounds. Vyas et al. (2015) reported ascorbic acid $(23.41 \mathrm{mg} / \mathrm{g})$, total flavonoid $(17.38 \mathrm{mg} / \mathrm{g})$, and total phenol $(3.21 \mathrm{mg} / \mathrm{g})$ in curry leaves, and which are associated with higher antioxidative capacity, thus act as very good sources of dietary antioxidants. It is reported that, $100 \mathrm{gm}$ of fresh leaves contains $8.7 \mathrm{~g}$ carbohydrate, $6 \mathrm{~g}$ protein, $1 \mathrm{~g}$ fat, $7560 \mu \mathrm{g} ß$-carotene, $830 \mathrm{mg}$ 
Calcium and $0.93 \mathrm{mg}$ Iron. Whereas, $100 \mathrm{~g}$ of dehydrated leaves contains $64.31 \mathrm{~g}$ carbohydrate, $12 \mathrm{~g}$ protein, $5.4 \mathrm{~g}$ fat, $5292 \mu \mathrm{g}$ ß-carotene, $2040 \mathrm{mg}$ Calcium and $12 \mathrm{mg}$ Iron (Khatoon et al., 2011).

The nutritive value of the curry leaf is comparable to other vegetables. Without realizing the nutritive value of curry leaves, it is usually not consumed along with food, but considered merely as a flavouring agent. The leaves can retain original flavour and other qualities even after drying. Curry leaves contain some important free amino acids like glycine, asparagin, serine, aspartic acid, theonine, alamine, proline, glutamic acid, tryptophan, leucine, tyrosine, alpha amino butyric acid, phenylalanine, isoleucine, lysine, arginine and histidine and Vitamin A (Wealth of India, 1962). Although curry leaf is a rich source of calcium, its bioavailability is affected due to the presence of high oxalic acid (1.35\% total oxalates; $1.15 \%$ soluble oxalates). Thus, identification of low oxalate and low oxalic acid genotypes will be an important step towards the effective utilization of curry leaves as leafy vegetable. The comparative nutrient value of curry leaf with some common vegetables as per ICMR (Aykroyd, 1996) is given below.

\begin{tabular}{|l|c|c|c|c|c|c|c|c|}
\hline Parameters & $\begin{array}{c}\text { Curry } \\
\text { leaf }\end{array}$ & $\begin{array}{c}\text { Cauli } \\
\text { flower }\end{array}$ & Cabbage & Radish & Carrot & $\begin{array}{c}\text { Dry } \\
\text { Pea }\end{array}$ & Tomato & $\begin{array}{c}\text { Dry } \\
\text { Chilli }\end{array}$ \\
\hline $\begin{array}{l}\text { Protein } \\
\text { (g/100g) }\end{array}$ & 6.1 & 2.6 & 1.8 & 0.6 & 0.9 & 19.7 & 0.9 & 15.9 \\
\hline $\begin{array}{l}\text { Carbohydrates } \\
\text { (g/100g) }\end{array}$ & 18.7 & 4.0 & 4.6 & 6.8 & 10.6 & 56.5 & 3.6 & 31.6 \\
\hline $\begin{array}{l}\text { Fat } \\
\text { (g/100g) }\end{array}$ & 1.0 & 0.4 & 0.1 & 0.3 & 0.2 & 1.1 & 0.2 & 6.2 \\
\hline $\begin{array}{l}\text { Calcium } \\
(\mathrm{mg} / 100 \mathrm{~g})\end{array}$ & 830 & 626 & 39 & 50 & 80 & 75 & 48 & 160 \\
\hline $\begin{array}{l}\text { Phosphorus } \\
\text { (mg/100g) }\end{array}$ & 57 & 107 & 44 & 20 & 530 & 298 & 20 & 370 \\
\hline $\begin{array}{l}\text { Iron } \\
(\mathrm{mg} / 100 \mathrm{~g})\end{array}$ & 7.0 & 40 & 0.8 & 0.5 & 22 & 5.1 & 0.4 & 2.3 \\
\hline $\begin{array}{l}\text { Vitamin-A } \\
\text { (I.U./100g) }\end{array}$ & 12600 & 51 & 2000 & 5 & 3150 & 66 & 585 & 576 \\
\hline $\begin{array}{l}\text { Vitamin-C } \\
\text { (mg/100g) }\end{array}$ & 4 & 56 & 124 & 17 & 3.0 & 0 & 27 & 50 \\
\hline
\end{tabular}

\section{MEDICINAL PROPERTIES OF CURRY LEAVES}

The different parts of curry leaf plant have many applications in Ayurveda and other traditional medicine system (Karthikar and Basu, 1935). Curry leaves are richest source of carbazole alkaloids, which have bioactive functions like anti-oxidant, anticancer, antidiabetic, and antiulcer (Igara et al., 2016). The carbazole alkaloids, mahanimbine and koenigine present in these leaves showed higher anti-oxidant activities (Ganesan et al. 2013). The extracts from roots, bark and leaves the are used in aboriginal medicine as tonic, anthelmintic, stomachic, analgesic, and as appetizing, carminative and stimulative agents for treating influenza, piles, itching, fever, dropsy, asthma, bronchial eruptions, diarrhoea, body aches, kidney pains, vomiting, fresh cuts and bites of poisonous animals ( Rana et al. 2004). The green leaves eaten raw for cure of dysentery (Dryry, 1978). The pulped bark and root of curry leaf plant are externally applied to cure eruptions and bites of poisonous animals (Dastur, 1970).

\section{INDUSTRIAL USE OF CURRY LEAVES}

Fresh leaves on steam distillation under pressure yields $1.6-3.7 \mathrm{~mL}$ volatile oils called curry leaf oil per kilogram (kg) of biomass (Syamasunder et al., 2012). The leaf oil is characterized by specific gravity of 0.9748 at $25^{\circ} \mathrm{c}$, saponification value of 5.2 and acid 
value of 3.8 (Wealth of India, 1962). Similarly, the mature fruits also yield a yellow colour volatile oil with specific gravity of 0.872 at $13^{\circ} \mathrm{c}$ and boiling point of $173.74^{\circ} \mathrm{C}$, having neroli-like odour and pepper like taste accompanied by agreeable sensation of coolness on the tongue. Similarly, yellow colour oil extracted from the seeds is known as limbolee oil (Drury, 1978). The leaf oil is used as a fixative for a heavy type of soap Perfumes. The essential oils extracted from other parts are also used in cosmetics industry and aromatherapy. Besides, the extracts from berries of curry leaf plant are used to prevent oxidative damage of meat and meat products (Yogesh et al., 2012). The curry leaves are incorporated in functional poultry meat finger sticks to improve lipid stability and antimicrobial quality of the products. This indicate that the effective use of curry leaves as an alternative to synthetic food preservatives in functional food industries (Aswathi et al., 2014). Besides, the curry leaf oil is also exported from India (Salikutty and Peter, 2001). The age of the leaves influences the oil composition, with advancing maturity there is gradual decrease in volatile oils and oleoresin (acetone extracted). The specific gravity of curry leaf oil is 0.97 while refrective index is 1.50 and optical rotation is +48 at $\left(25^{\circ} \mathrm{C}\right)$. The saponification value of this oil is 5.2 and after acetalation it is 54.6

\section{COMMERCIAL CULTIVATION OF CURRY LEAVES IN INDIA}

Besides, naturalized forest and homestead gardens habitation, the curry leaves are also being cultivated in large commercial scale in several districts of Southern India due to increasing export potential, low inputs for cost of cultivation, adoptability to small and marginal lands, assured income, perennial nature, and constant domestic demand in local markets. The large scale commercial cultivation of curry leaves is seen in Guntur, Nellore, Anantapur and Krishna districts of Andhra Pradesh, Sanga Reddy, Medak, Siddipet, Kama Reddy and Nizamabad districts of Telangana and Coimbatore, Tiruppur, Selem and Thoothukudi districts of Tamil Nadu (Mohan, 2012) (Fig. 2).

\section{DIVERSITY OF CURRY LEAVES IN INDIA}

Curry leaf plant is native to India. A tremendous variability exists at morphological, bio-chemical and molecular level for this crop. Several chemo-types and morpho-types have been reported in curry leaves of Indian origin (Rao et al., 2011; Sivakumar and Meera, 2013). There are four genetically diverse chemotypes of curry leaves such as $\beta$-pinene, $\alpha$-pinene, $\beta$ - caryophyllene and $\beta$-phellandrene were reported in India (Raina et al. 2002). Similarly, the essential oils extracted from leaves of curry plants from various locations of Western Ghats, India, were categorized into 4 chemotypes namely, $\beta$-phellandrene, sabinene, $\alpha$-pinene and $\beta$ caryophyllene (Syamasunder et al., 2012)

Three different morphotypes with respect to color and size of leaves, habitat of the plant, flavor of the plant as, Brown/Gamthi (GM), Regular (RE) and Dwarf (DF), are identified in India. Brown types are most fragrant slowly growing; leaves are small, thick with serrated edges and dark brown in color. Regular types are fastest growing and grow as tree, greater in look, and leaves are exstipulate, bipinnately compound and long having reticulate venation with dark in color and available throughout the country. Dwarf types grows as a shrub with moderate growth, spreading branches and appears as a bush, leaves are light green, look like a regular type but aromacity of its own. All three morphotpes differ for intensity of flavor. The radical scavenging capacity of methanolic extracts of three morpho-types was in the order of Gamthi $>$ Dwarf $>$ Regular, with $\mathrm{IC}_{50}$ values of 171,365 and $471(\mathrm{~g} / \mathrm{ml})$, respectively (Sivakumar and Meera, 2013). Besides, Gamthi $(532.8 \mathrm{mg} / \mathrm{ml})$ had more phenolic content over dwarf $(168.2 \mathrm{mg} / \mathrm{ml})$ and Regular $(111.6 \mathrm{mg} / \mathrm{ml})$ types and $6.01,4.82$ and $3.58 \mathrm{mg} / \mathrm{ml}$ of flavonoids were reported in GM, DF and RE, respectively (Sivakumar and Meera, 2013). Further, curry leaves exhibited huge variability with respect to chemical composition of essential oils over locations and seasons (Syamasunder et al., 2012).

\section{GENETIC IMPROVEMENT OF CURRY LEAVES IN INDIA}

Genetic improvement of curry leaves interms of germplasm collection, characterization and conservations are still in nascent stage in India. Majority of curry leaf growing farmers on commercial scale have adapted locally available genotypes in which genetic potential for yield, resistance to pests and diseases and information on quality is unknown. However, two improved varieties of curry leaves 
namely, DWD-1 and DWD-2 (Suwasini) are genetically distinct genotypes, released from University of Agricultural Sciences (UAS), Dharwad for commercial cultivation. Besides, a local landrace called Senkaampu is very popular in different parts of Tamil Nadu due its good aroma and high oil content. Recently, the research efforts are initiated at ICAR-Indian Institute of Horticultural Research (IIHR), Bengaluru for genetic improvement of curry leaf for improved yield and quality and resistance pests and disease. Over 100 germplasm of curry leaves were collected from different parts of the country and successfully established in field gene bank at ICAR-IIHR, Bengaluru. Further, efforts are being made to characterize them and registered with national gene bank for further utilization in research programmes in India.

\section{FUTURE THRUST}

1. Area expansion under commercial cultivation: In India, the commercial cultivation of curry leaves is confined to few distracts of Tamil Nadu, Andhra Pradesh, Telangana and Karnataka covering more $90 \%$ of commercial cultivation. However, curry leaf can easily fit to other dry land parts of the country.

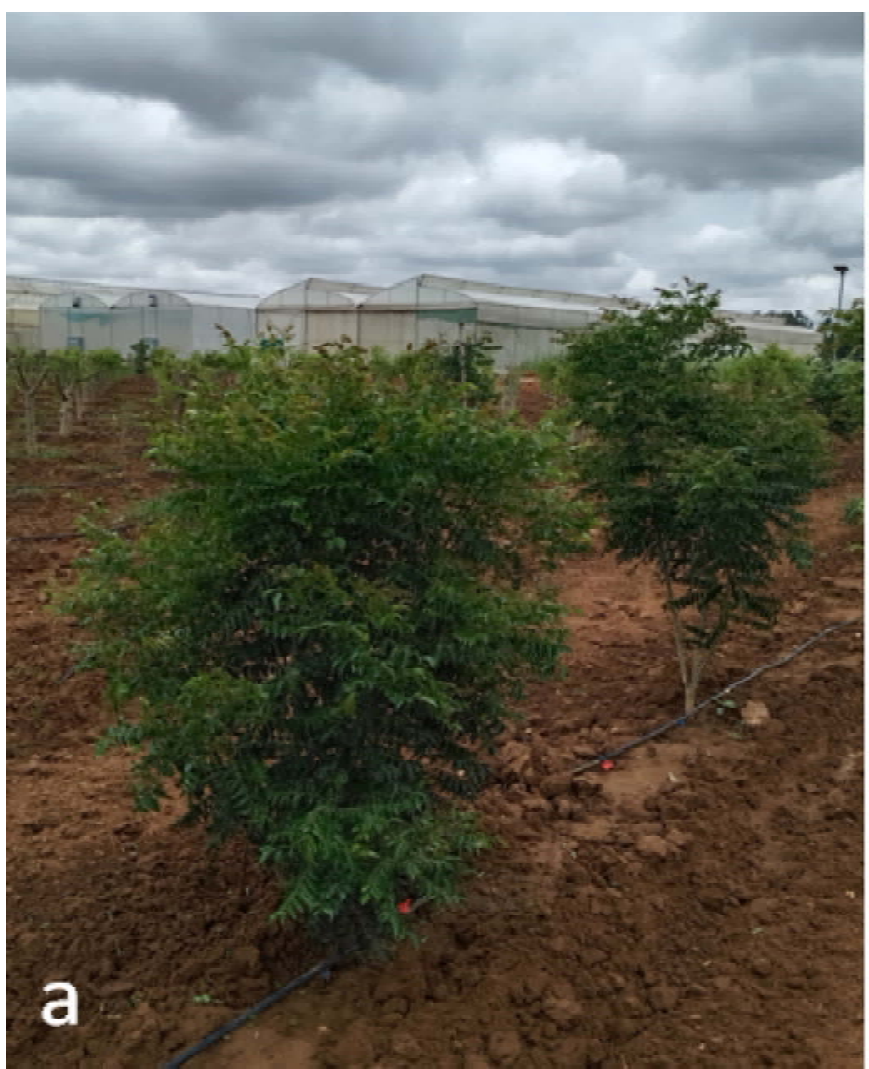

Besides, it assures income security to small and marginal farmers in rainfed ecosystems. Thus, there is a huge scope to expand curry leaf cultivation to nonconventional arid and semi-arid regions of central, western and north-east parts of the country.

2. Conservation of PGR in Curry leaves: Curry leaf is native to India and tremendous diversity exists for this crop. To understand the extant of variability for important economic traits and identification of trait specific genotypes requires comprehensive exploration of PGR, characterization and documentation. There should be a system of regular exchange of germplasm among the researchers.

\section{Development of DUS guidelines and} protection of farmer's varieties: In various parts of India, the farmers are popularly growing local cultivars of curry leaves. They known to possess unique traits and have economic importance. However, there is no internationally or nationally accepted DUS test guidelines available in curry leaves; which is a mandatory requirement to register and protect farmer's varieties under PPV\&FRA, New Delhi. Thus, there is an urgent need to develop

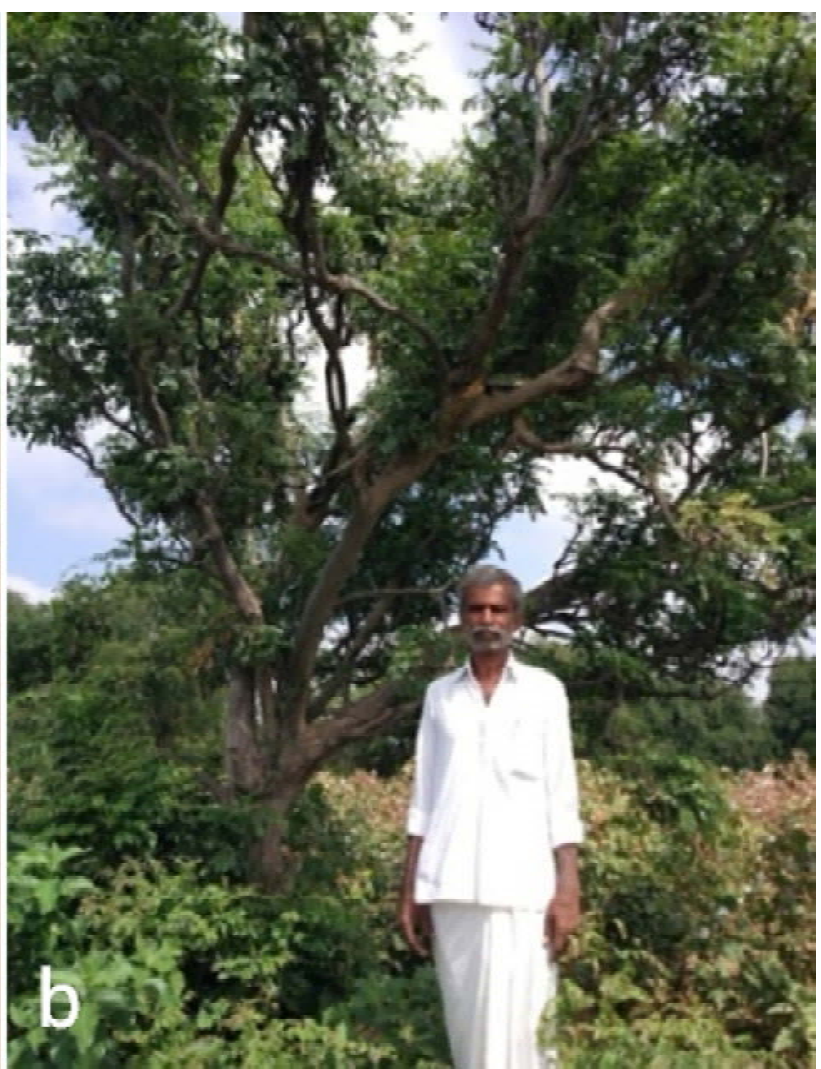

Fig. 1. Curry leaf plant (bushy) (a) and small tree (b). 
internationally or nationally accepted DUS test guidelines in curry leaves.

\section{Comprehensive research efforts in curry}

leaves: A breeding program inclusive of increased use of genomic resources in PGR management, identification of trait specific genotypes and trait discovery, successful introgression into elite genetic background is need of the hour. Further, much intensive effort towards ideotype breeding in curry leaves is required for development of ever green and bushy type with quick generation capacity after pruning.

\section{CONCLUSION}

Curry leaves is a multi-utility leafy vegetable with numerous benefits. It is known to enhance the palatability of food and is a rich source of nutrients and valuable volatile oils. It is an easily cultivable perennial crop with low input cost, being grown as a small tree in homestead gardens; intercrop with other perennial crops and also on commercial scale. Due to its perenniality, it can provide assured income for 10-12 years of planting with minimum annual expenditure. Though curry leaf is an ancient crop native to India, its nutritive and medicinal values have not been fully appreciated yet. Efforts towards characterization and conservation of genetic wealth and genetic improvement of curry leaf have not been addressed adequately. Thus, there is need to popularize and utilize this native crop with adequate research and institutional efforts.

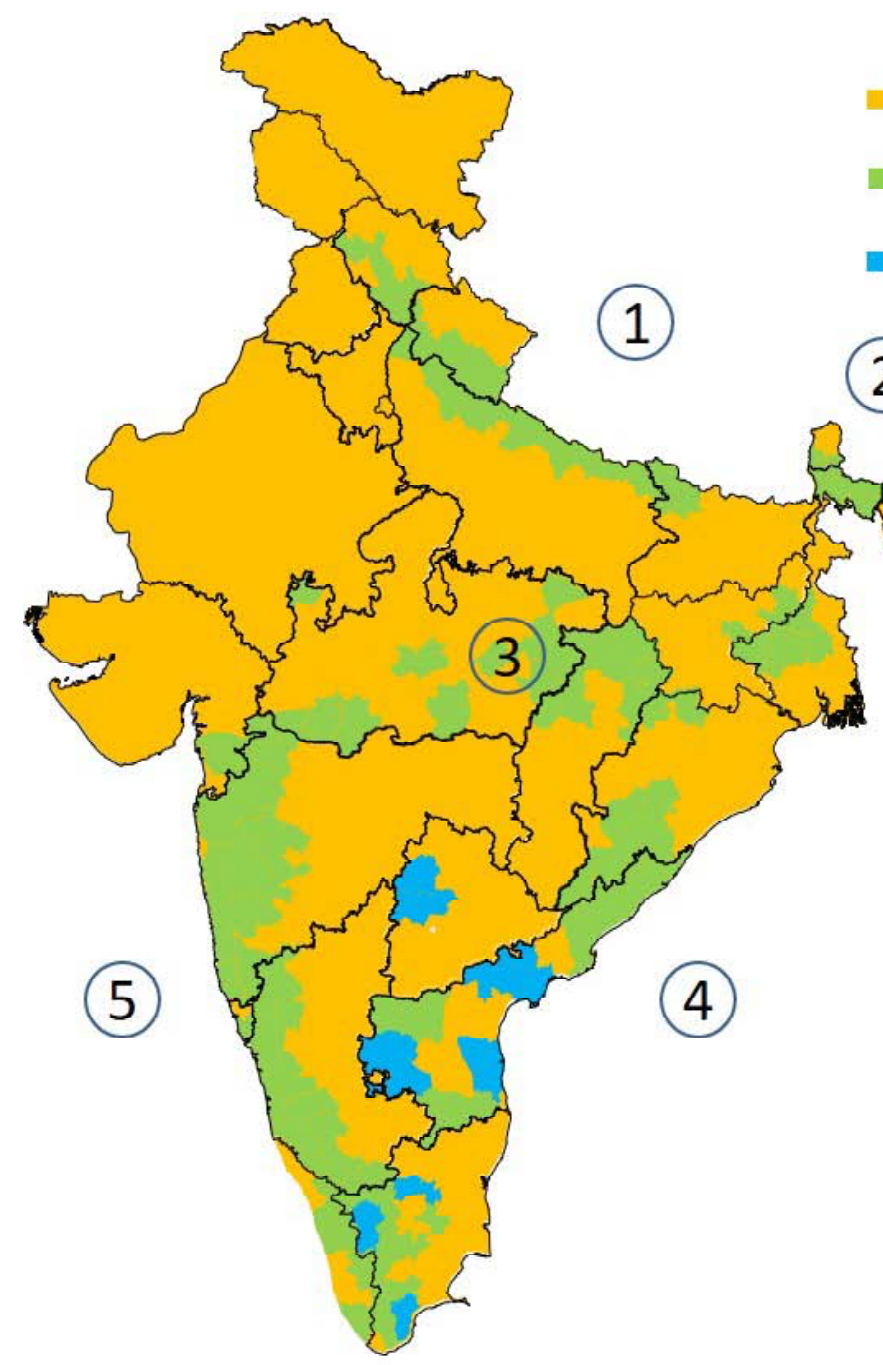

\section{Legends \\ Growing in homestead gardens for household purpose (states) \\ Occurrence in naturalized \& wild habitat, ethno- botanical \& household use (Districts) Large scale commercial cultivation (Districts)}

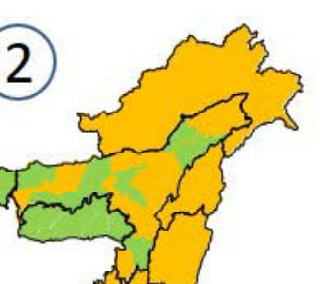

\section{Major regions of diversity}

1. Foothills of Himalaya (Shivalik \& Tarai regions).

2. North-east region (foothills of Sikkim, Darjeeling hills, Assam valley, Meghalaya hills).

3. Middle India (Chota-Nagapur plateau \& adjoining hills ).

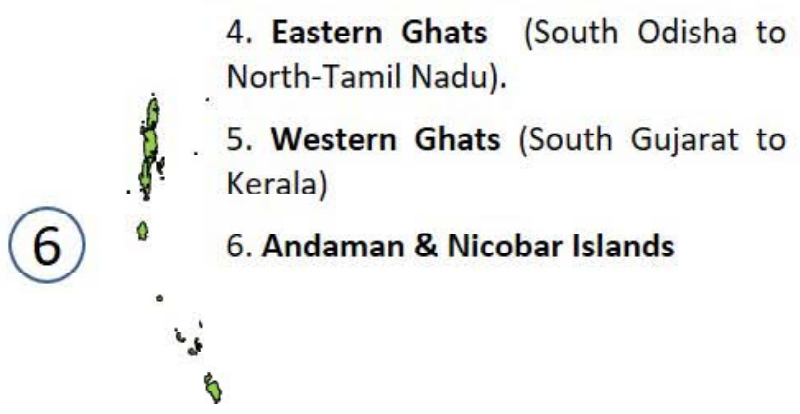

Fig. 2. Diversity map of curry leaves (Murraya koenigii (L.) Spreng) in India. 


\section{REFERENCES}

Anonymous. 1962. The wealth of India: The raw materials. Council of Scientific and Industrial Research, India, 6: 446-448.

Aswathi, P.B., Biswas, A.K., Beura, C.K., Yadav, A.S., Khatke, P.A. 2014. A study on the antimicrobial and antioxidant effects of Murraya koenigii on functional poultry meat finger sticks. Int. J. Meat. Sci., 4:15 21.

Aykroyd, W. R. 1966. The Nutritive Value of Indian Foods and the Planning of Satisfactory Diets, Indian Council of Medical Research, New Delhi, 6th ed: 53-58.

Dastur, J. F. 1970. Meditional Plants of India and Pakistan, Third Edn. D. B. Taraporevala Sons \& Co. Private Ltd., Bombay: 115.

Drury, H. C. 1978. The useful plants of India. Second Edn. William, H. Allen \& Co., London. 78.

Ganesan, P., Phaiphan, A., Murugan, Y., Baharin, B.S. 2013. Comparative study of bioactive compounds in curry and coriander leaves: An update. Journal of Chemical and Pharmaceutical Research, 5(11):590-594.

Igara C.E., Omoboyowa, D.A., Ahuchaogu, A.A., Orji, N.U., Ndukwe, M.K. 2016. Phytochemical and nutritional profile of Murraya koenigii (Linn) Spreng leaf. Journal of Pharmacognosy and Phytochemistry. 5(5):07-09.

Joseph, S. and Peter, K. V. 1985. Curry leaf (Murraya koenigii), perennial nutritious leafy vegetable. Economic Botony, 39: 68-73.

Kartikar, K.R. and Basu, B. D. 1935. Indian meditional plants. Second Edn. M/s. Bishen Singh Mahendra Pal Singh, Dehra Dun. 1: 474-475.

Khatoon, J., Verma, A., Chacko, N and Sheikh, S. (2011). Utilization of dehydrated curry leaves in different food products. Indian Journal of Natural Products and Resources, 2(4): 508-511

Mohan, R. S. 2012. Curry leaf campaign. Spice India. 25 (7): 10-12.

Raghuvan, R.S. 1957. Chromosome number of Indian Meditational Plants. Proc. Indian. Acad. Sci. Sect. B.45, 6: 294-298.

Raina, V.K., Lal, R.K., Tripathi, S., Khan, M., Syamasundar, K.V. and Srivastava, S.K. 2002. Essential oil composition of genetically diverse stocks of Murraya koenigii. Flavour and Fragrance Journal, 17: 144-146.
Rana, V. S., Juyal, J. P., Rashmi \& Blazquez, M. A. 2004. Chemical constituents of the volatile oil of Murraya koenigii leaves. International Journal of Aromatherapy, 14: 23-25.

Rao, B. R. R., Rajput, D.K. and Mallavarapu, G.R. 2011. Chemical diversity in curry leaf (Murraya koenigii) essential oils. Food Chemistry, 126 : 989-994.

Reddy, B. M., Dhanpal, C. K. and Lakshmi B. V. S. 2018. A review on curry leaves (Murraya koenigii): versatile multi-potential medicinal plant. International Journal of Advances in Pharmacy Medicine and Bioallied Sciences, 6(1): 31-41.

Salikutty, J. and Peter, K. V. 2001. Curry leaf (In) Hand book of herbs and spices (Ed.) K. V. Peter, Wood Head Publishing Company, England.

Satyavati, G.V., Gupta A.K. and Tendon N. 1987. Medicinal Plants of India, Indian council of medical research, New Delhi India, vol. 2: 289299.

Singh, S, More, P.K., Mohan S.M. 2014. Curry leaves (Murraya koenigii) - A miracle plant. Indian J. Sci. Res., 4(1): 46-52.

Sivakumar, ChV. and Meera, I. 2013. Anti-oxidant and biochemical activities of three morphotypes of Murraya koenigii L. from Uttarakhand. J food process Technol. 4: 246.

Smith, A. C. 1985. Flora vitiensis nova: A new flora of Fiji (Spermatophytes only), Lavai, Kauai, Hawaii: Pacific Tropical Botanic Garden, 3: pp 758.

Syamasundar, K.V., Srinivasulu, B., Gowda, A.P.L., Srinivasaiyer, R., Rao, R.R. 2012. Chemo variations of wild curry leaf (Murraya koenigii spreng.) from Western Ghats of India. Journal of Pharmacognosy, 6(2): 126-130.

Verghese, J. 1989. Indian curry leaf. Perfumer and Flavorist, 14(3): 69-70.

Vyas, V.G., Kandoliya, U.K., Vidhani, S.I., Parmar, H.J., Bhalani, V.M., Golakiya, B.A. 2015. Heavy metal deposition and phytochemical characterization of curry leaves (Murraya koenigii). Int. J. Curr. Microbiol. Appl. Sci., 4:839-43.

Yogesh, K., Jha, S.N., Yadav, D.N. 2012. Antioxidant activities of Murraya koenigii (L.) Spreng berry extract: Application in refrigerated $\left(4 \pm 1^{\circ} \mathrm{C}\right)$ stored meat homogenates. Agric. Res., 1 : 183-189. 